\title{
Comparative Ribosomal Protein Sequence Analyses of a Phylogenetically Defined Genus, Pseudomonas, and Its Relatives
}

\author{
KOZO OCHI* \\ National Food Research Institute, 2-1-2 Kannondai, Tsukuba, Ibaraki 305, Japan
}

\begin{abstract}
I analyzed various families of ribosomal proteins obtained from selected species belonging to the genus Pseudomonas sensu stricto and allied organisms which were previously classified in the genus Pseudomonas. Partial amino acid sequencing of $\mathrm{L} 30$ preparations revealed that the strains which I examined could be divided into three clusters. The first cluster, which was assigned to the genus Pseudomonas sensu stricto, included Pseudomonas aeruginosa, Pseudomonas putida, Pseudomonas mendocina, and Pseudomonas fluorescens. The second cluster included Burkholderia pickettii and Burkholderia plantarii. The third cluster, which was a deeply branching cluster in the stem of gram-negative bacteria, included Brevundimonas diminuta and Brevundimonas vesicularis. Despite the different levels of conservation of the $\mathbf{N}$-terminal sequences of ribosomal protein families (the highest level of similarity was $74 \%$ for $L 27$ proteins and the lowest level of similarity was $42 \%$ for L30 proteins), similar phylogenetic trees were constructed by using data obtained from sequence analyses of various ribosomal protein families, including the $\mathrm{S20}, \mathrm{S21}, \mathrm{L27}, \mathrm{L29}, \mathrm{L31}, \mathrm{L32}$, and $\mathrm{L33}$ protein families. Thus, I demonstrated the efficacy of ribosomal protein analysis in bacterial taxonomy.
\end{abstract}

The Pseudomonadaceae is a very large and important family of gram-negative bacteria and includes the genera Pseudomonas, Xanthomonas, Zoogloea, and Frateuria $(19,20)$. The genus Pseudomonas, a genus which is one of the most complex groups of gram-negative bacteria known and which is phenotypically similar to many other genera, is particularly interesting because Pseudomonas strains not only are medically important as opportunistic pathogens that cause disease in animals and humans (reviewed by Palleroni [21]) but also are agriculturally important as phytopathogens (reviewed by Schroth et al. [25]). The genus Pseudomonas as defined in Bergey's Mannual of Systematic Bacteriology (19) is an aggregate of gram-negative bacteria which share many gross phenotypic similarities that do not necessarily correlate with the true phylogenetic relationships of the organisms; it has been recognized that the members of this taxon belong to several genera and cannot be considered members of a single genus. A limited number of strains have been used to show that the genus Pseudomonas can be divided into at least five distinct groups on the basis of rRNA-DNA hybridization data, and some of these groups are as distantly related to each other as they are to Escherichia coli (23). The subdivision of the genus Pseudomonas into five rRNA similarity groups has been confirmed in many laboratories by using modified rRNA-DNA hybridization techniques, rRNA sequencing, and biochemical techniques involving analysis of cell wall components or determination of biosynthetic pathways and their regulatory mechanisms $(3-5,26,27,31,32$, 39). It is now recognized that the genus Pseudomonas sensu stricto should be restricted to rRNA group I, which contains the type species, Pseudomonas aeruginosa. Consequently, the members of rRNA groups other than group I have been placed in other genera or in newly created genera; these genera include Stenotrophomonas (22), Comamonas (30), Acidovorax (34), Hydrogenophaga (33), Sphingomonas (41), Burkholderia (40), Telluria (2), and the recently proposed genus Brevundimonas (26).

During the last few years I have developed a novel method

\footnotetext{
* Phone: 0298-38-8125. Fax: 0298-38-7996.
}

to identify and classify actinomycetes. This method depends on the electrophoretic heterogeneity of the ribosomal AT-L30 proteins of actinomycete genera $(10-12,18)$. N-terminal amino acid sequencing of the AT-L30 proteins has also been used successfully to determine the taxonomic status of various actinomycete genera (14-17). Moreover, amino acid sequence homology among L30 proteins (which are homologous to actinomycete AT-L30 proteins) obtained from other bacteria has been a useful standard for classification at the genus level (13). The aims of this study were (i) to use ribosomal protein sequencing as an additional approach for taxonomic analysis of heterogeneous bacterial groups and (ii) to evaluate by comparative sequencing different proteins from the same strains to determine which proteins might be most useful as alternatives to RNA data in phylogenetic analyses.

\section{MATERIALS AND METHODS}

Bacterial strains. The following strains were used in this study: Bacillus stearothermophilus NCA 1503, Brevundimonas diminuta JCM $2788^{\mathrm{T}}$ (= ATCC $11568^{\mathrm{T}}$ ) $\left(\mathrm{T}=\right.$ type strain), Brevundimonas vesicularis $\mathrm{JCM} 1477^{\mathrm{T}}$ (= ATCC $\left.11426^{\mathrm{T}}\right)$, Burkholderia pickettii JCM $5969^{\mathrm{T}}$ (= ATCC $27511^{\mathrm{T}}$ ), Burkholderia plantarii JCM $5492^{\mathrm{T}}\left(=\right.$ NIAES $1723^{\mathrm{T}}$ ), Escherichia coli $\mathrm{K}-12$, Flavobacterium gleum JCM $2410^{\mathrm{T}}\left(=\right.$ NCTC $\left.11432^{\mathrm{T}}\right)$, Leuconostoc mesenteroides JCM $6124^{\mathrm{T}}(=$ ATCC $8293^{\mathrm{T}}$ ), Pseudomonas aeruginosa ATCC $10145^{\mathrm{T}}$, Pseudomonas fluorescens JCM $5963^{\mathrm{T}}\left(=\right.$ ATCC $\left.13525^{\mathrm{T}}\right)$, Pseudomonas mendocina JCM 5966 ${ }^{\mathrm{T}}(=$ ATCC $25411^{\mathrm{T}}$ ), Pseudomonas putida JCM $3697^{\mathrm{T}}$ (= ATCC $12633^{\mathrm{T}}$ ), Staphylococcus aureus JCM 2151 (= ATCC 6538P), and Thermoactinomyces vulgaris JCM $3162^{\mathrm{T}}$ (= DSM 43016 ${ }^{\mathrm{T}}$ ). Almost all of these strains were type strains that were obtained from the Japan Collection of Microorganisms, Wako, Saitama, Japan, and the American Type Culture Collection, Rockville, Md. Burkholderia plantarii (formerly Pseudomonas plantarii) is a new species that was recently isolated from rice seedlings (1). The strains were grown to the mid-exponential phase in soluble starch-Polypeptone-yeast extract medium (11).

Two-dimensional PAGE. The method used for two-dimensional polyacrylamide gel electrophoresis (PAGE) has been described in detail previously (10). The protein spots corresponding to S20, S21, L24, L27, L29, L30, L31, L32, and L33 proteins were identified after each slab gel had been subjected to blotting by dry electrophoresis and staining with Coomassie blue, as described previously (16).

Determination of amino acid sequence. An amino acid sequence analysis of each ribosomal protein was performed as described by Ochi and Miyadoh (17), using a model $470 \mathrm{~A}$ protein sequencer (Applied Biosystems). The method which I used was based on the Edman degradation, and determination of a maximum of $25 \mathrm{~N}$-terminal amino acids was possible when about 100 pmol of ribosomal protein preparation was used. In $E$. coli the $\mathbf{L} 30$ protein consists of 58 amino acid 


Pae Ala-----
Phr

FIG. 1. Primary structures of $\mathrm{N}$ termini of the $\mathrm{L} 30$ proteins from strains belonging to the genus Pseudomonas and allied genera and representative gram-positive bacteria. The question marks indicate amino acids that were not determined. The dotted lines indicate deletions. The amino acids that are conserved in gram-positive or gram-negative bacteria are enclosed in boxes. The data for E. coli K-12 and Bacillus stearothermophilus NCA 1503 are from references 24 and 7 , respectively. The data for $S$. aureus, $L$. mesenteroides, and T. vulgaris are from reference 13. Abbreviations: Bst, Bacillus stearothermophilus NCA 1503; Bdi, Brevundimonas diminuta JCM $2788^{\mathrm{T}}$ (= ATCC $11568^{\mathrm{T}}$ ); Bve, Brevundimonas vesicularis $\mathrm{JCM} 1477^{\mathrm{T}}\left(=\mathrm{ATCC} 11426^{\mathrm{T}}\right)$; Bpi, Burkholderia pickettii $\mathrm{JCM} 5969^{\mathrm{T}}\left(=\mathrm{ATCC} 27511^{\mathrm{T}}\right) ; \mathrm{Bpl}$, Burkholderia

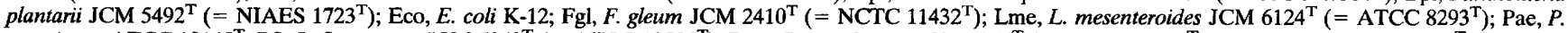

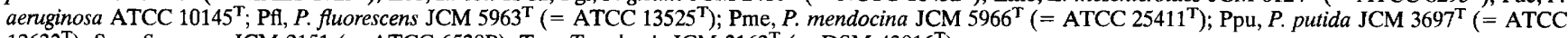
$12633^{\mathrm{T}}$ ); Sau, $S$. aureus JCM 2151 (= ATCC 6538P); Tvu, T. vulgaris JCM $3162^{\mathrm{T}}$ (= DSM $43016^{\mathrm{T}}$ ).

residues. The $25 \mathrm{~N}$-terminal amino acids, therefore, represent nearly one-half of the whole L30 protein, assuming that the L 30 proteins of E. coli and Pseudomonas species are the same.

\section{RESULTS}

Amino acid sequences of L30 proteins. I first analyzed L30 proteins obtained from members of the genus Pseudomonas and related genera and from selected gram-positive bacteria for reference purposes (Fig. 1). To express quantitatively the levels of similarity of the amino acid sequences, I determined the frequency of appearance of each amino acid in the 25 $\mathrm{N}$-terminal amino acids of each $\mathrm{L} 30$ protein and compared the sequences (Table 1). (Deletions were weighted in the level of similarity calculations, but nondetermined positions were not.) As shown in Fig. 1 and Table 1, it is apparent that the eight Pseudomonas species which I studied can be placed in three clusters. On the basis of the levels of similarity of the amino acid sequences, I constructed a dendrogram (Fig. 2). On this tree, the first cluster contained $P$. aeruginosa, $P$. putida, $P$. mendocina, and $P$. fluorescens; the second cluster contained Burkholderia pickettii and Burkholderia plantarii; and the third cluster contained Brevundimonas diminuta and Brevundimonas vesicularis. Strikingly, this classification was entirely consistent with the results of rRNA-DNA homology and rRNA sequenc-

TABLE 1. Levels of amino acid sequence similarity for $L 30$ proteins ${ }^{a}$

\begin{tabular}{|c|c|c|c|c|c|c|c|c|c|c|c|c|c|}
\hline \multirow[b]{2}{*}{ Strain } & \multicolumn{13}{|c|}{$\%$ Amino acid sequence similarity with: } \\
\hline & 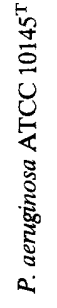 & 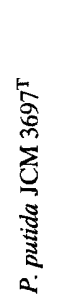 & 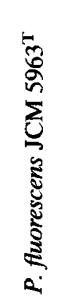 & 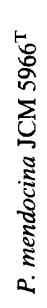 & 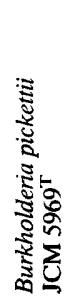 & 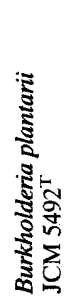 & 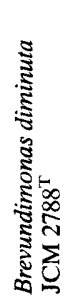 & 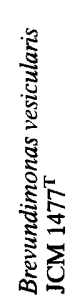 & $\underset{4}{\pi}$ & 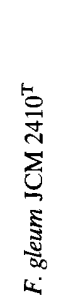 & 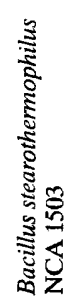 & 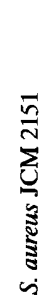 & 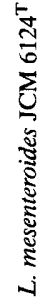 \\
\hline P. putida JCM $3697^{\mathrm{T}}$ & 95 & & & & & & & & & & & & \\
\hline P. fluorescens $\mathrm{JCM} 5963^{\mathrm{T}}$ & 70 & 75 & & & & & & & & & & & \\
\hline P. mendocina $\mathrm{JCM} 5966^{\mathrm{T}}$ & 86 & 81 & 71 & & & & & & & & & & \\
\hline Burkholderia pickettii JCM $5969^{\mathrm{T}}$ & 59 & 59 & 47 & 47 & & & & & & & & & \\
\hline Burkholderia plantarii JCM 5492 & 59 & 59 & 47 & 47 & 82 & & & & & & & & \\
\hline Brevundimonas diminuta JCM $2788^{\mathrm{T}}$ & 28 & 33 & 28 & 26 & 28 & 28 & & & & & & & \\
\hline Brevundimonas vesicularis $\mathrm{JCM} 1477^{\mathrm{T}}$ & 28 & 33 & 28 & 28 & 18 & 35 & 68 & & & & & & \\
\hline E. coli $\mathrm{K}-12$ & 45 & 41 & 41 & 43 & 50 & 50 & 42 & 32 & & & & & \\
\hline F. gleum JCM $2410^{\mathrm{T}}$ & 47 & 47 & 42 & 40 & 53 & 41 & 33 & 22 & 52 & & & & \\
\hline Bacillus stearothermophilus NCA 1503 & 17 & 17 & 22 & 17 & 33 & 33 & 26 & 21 & 43 & 36 & & & \\
\hline S. aureus JCM 2151 & 18 & 18 & 23 & 17 & 33 & 33 & 28 & 21 & 45 & 43 & 81 & & \\
\hline L. mesenteroides $\mathrm{JCM} 6124^{\mathrm{T}}$ & 27 & 23 & 23 & 27 & 11 & 22 & 11 & 16 & 43 & 29 & 43 & 43 & \\
\hline T. vulgaris JCM $3162^{\mathrm{T}}$ & 17 & 17 & 17 & 17 & 33 & 33 & 21 & 16 & 39 & 36 & 81 & 71 & 43 \\
\hline
\end{tabular}

${ }^{a}$ The levels of sequence similarity for $25 \mathrm{~N}$-terminal amino acids of the L30 proteins were determined by using the data shown in Fig. 1 . Positions that were not determined were not weighted in the calculations. 

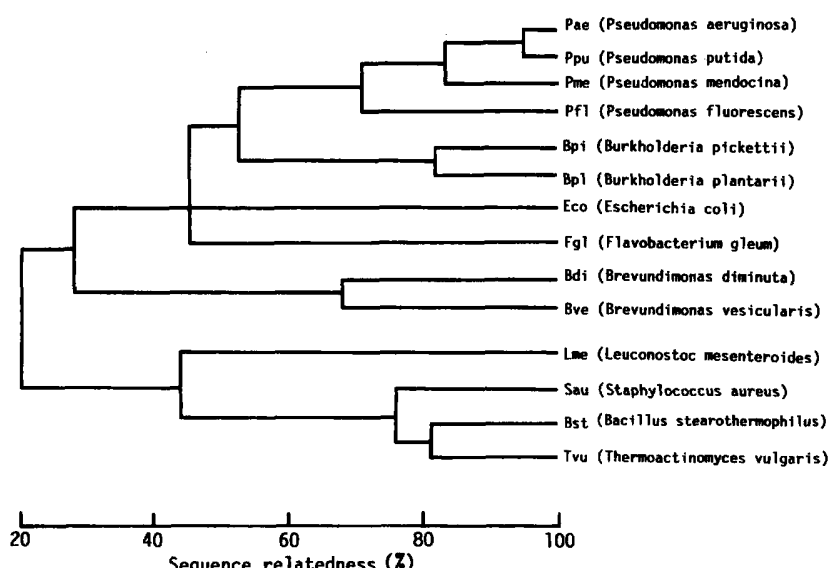

FIG. 2. Clustering based on $\mathrm{L} 30$ protein amino acid sequence similarity values. The dendrogram was constructed by using the data in Fig. 1 and Table 1.

ing studies performed previously by other researchers $(4,23$, $26,39,40)$. Within each of the clusters, the levels sequence homology were more than $70 \%$, whereas the levels of sequence homology between clusters were less than $50 \%$. In particular, the third cluster, which contained Brevundimonas diminuta and Brevundimonas vesicularis, was even more distantly related to the Pseudomonas cluster than it was to $E$. coli or F. gleum (Fig. 2).

Amino acid sequences of other ribosomal protein families. Bacterial ribosomes consist of three species of RNA (5S, 16S, and 23S RNA) and more than 50 species of ribosomal proteins, which form $30 \mathrm{~S}$ and $50 \mathrm{~S}$ subunits in whole (70S) ribosome units (reviewed in references 9, 29, 35, and 36). I analyzed various families of ribosomal proteins prepared from large (50S) and small (30S) subunits. The results of sequence analyses of ribosomal protein families S20 (identical to L26), S21, L24, L27, L29, L31, L32, and L33 are shown in Fig. 3 and 4. (The prefixes $\mathrm{L}$ and $\mathrm{S}$ indicate that ribosomal proteins are from large [50S] and small [30S] subunits, respectively; in this paper, I use the same number that is used for the equivalent $E$. coli ribosomal protein.) I found considerable differences in the levels of conservation among the ribosomal protein families. The average levels of amino acid sequence similarity obtained for every combination of Pseudomonas species tested were as follows (in order of conservation); L27, 74\%; L32, 64\%; S20,
55\%; L33, 53\%; S21, 53\%; L29, 52\%; L31, 49\%; and L30, $42 \%$. The L30 proteins exhibited the lowest level of conservation observed among the ribosomal protein families examined. On the basis of the data in Fig. 3 and 4, dendrograms were constructed (Fig. 5). Interestingly, despite the considerable differences in the levels of conservation, similar branching orders were obtained, except that the phylogenetic position of $E$. coli as determined by the L30 or L32 analysis was somewhat different from the position based on other ribosomal protein analyses. $P$. aeruginosa and $P$. mendocina were always relatively closely related to $E$. coli, while Brevundimonas diminuta and Brevundimonas vesicularis were always very distantly related to members of the genera Pseudomonas and Burkholderia (Fig. 5).

\section{DISCUSSION}

Although only a limited number of species and strains were used in this study, one of my major conclusions is that my data do not contradict former data and former conclusions $(4,19$, $26,39,40)$. It is evident from Fig. 2 that the second cluster, which contains Burkholderia picketii and Burkholderia plantarii (which correspond to rRNA group II of Palleroni et al. [23]), and the third cluster, which contains Brevundimonas diminuta and Brevundimonas vesicularis (which correspond to rRNA group IV), should be assigned to new genera that are distinct from the genus Pseudomonas sensu stricto. Thus, despite the entirely different approaches used by workers in different laboratories, the same conclusion was reached. As discussed previously in dealing with taxonomy of the genera Bacillus, Escherichia, and Staphylococcus (13), L30 protein analyses appear to be useful for studying the taxonomy of not only actinomycetes but also other bacteria. The sharp separation of grampositive bacteria from gram-negative bacteria on my phylogenetic tree (Fig. 2) supports the efficacy of ribosomal protein analysis for bacterial taxonomy. Taxonomists argue about the species concept and the genus concept in bacteria. My finding that even the genus Pseudomonas sensu stricto is heterogeneous is important. This fact has been overlooked by many microbiologists who are not interested in taxonomy. In a previous study I demonstrated that $T$. vulgaris and Thermoactinomyces thalpophilus, whose classification at the species level has been confused, could be clearly distinguished by a difference in their L30 amino acid sequences (13). Among the members of the genus Pseudomonas, $P$. aeruginosa, the type species of the genus, is the most sharply defined species and one of the

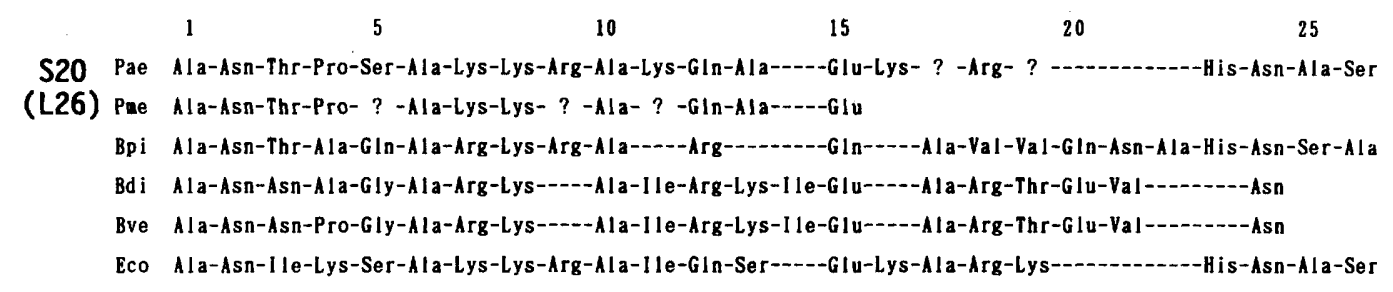

S21 Pae Pro-Ala-Val-Lys-Val-Lys-Glu-Asn-Glu-Pro-Phe-Asp-Val-Ala

Pme Pro-Ala-Val-Lys-Val-Lys-Glu-Asn-Glu-Pro-Phe-Asp-Val-Ala-Leu-Arg-Arg-Phe-Lys

Bpi Thr-Thr-Ile-Arg-Leu- ? -Glu-Asn-Glu-Pro-Val-Glu-Val-Ala-Leu-Arg

Bdi Val-GIn-lle-Phe-Val- ? -Asp-Asn-Asn----Val-Asp-GIn-Ala-Leu-Lys

Bve Val-GIn-Ile-Phe-Val-Arg-Asp-Asn-Asn-----Val-Asp-GIn-Ala-Leu-Lys-Ala-Leu-Lys

Eco Pro-Val-Ile-Lys-Val-Arg-Glu-Asn-Glu-Pro-Phe-Asp-Val-Ala-Leu-Arg-Arg-Phe-Lys

FIG. 3. Primary structures of the $\mathrm{N}$ termini of the S20 and S21 proteins from strains belonging to the genera Pseudomonas, Burkholderia, Brevundimonas, and Escherichia. For an explanation of the abbreviations and other details see the legend to Fig. 1. 
L24 Bdi Ala-Ala-Lys-Ile-Lys-Lys-Gly-Asp-Asn-Val-Val-Val-Leu-Thr-Gly

Bve Ala-Ala-Lys-Ile-Lys-Lys-Gly-Asp-Arg

Eco Ala-Ala-Lys-Ile-Arg-Arg-Asp-Asp-GIu-Val-Ile-Val-Leu-Thr-Gly

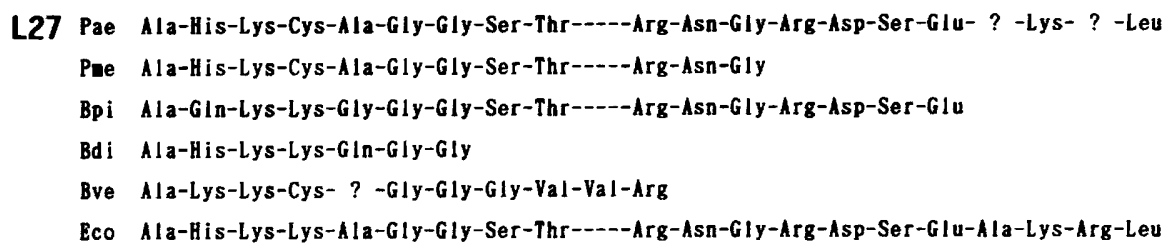

L29 Pae Met-Lys-Ala-Asn-GIu-Leu-Arg-GIu-Lys-Ser-Val-Glu-GIn-Leu-Asn-GIu-GIn-Leu-Leu-Gly

Pae Met-Lys-A1a-Thr-GIu-Leu-Arg-GIu-Lys-Ser-Ala-GIn-GIn-Leu-Asn- ? -GIn-Leu-Leu

Bpi Met-Lys-Ala-Ser-GIu-Leu-Arg-Asp-Lys-Asp-Val-Ala-Gly-Leu-GIn-Glu-----Leu

Bdi Thr-Lys-Ile-Ala-Asp-Leu-Arg-Ser-GIn-Thr-Val-Asp-GIn-Leu-Ser-Asp- ? -Leu- ? -Lys-Leu

Bve Thr-Lys-Ile-Ala-Asp-Leu-Arg-Ser-GIn-Thr-Thr-Asp-GIn-Leu-Ser-Asp-Glu-Leu-Leu-Lys-Leu- ? -Lys-GIu-GIn

Eco Yet-Lys-Ala-Lys-GIu-Leu-Arg-Gilu-Lys-Ser-Val-GIu-GIu-Leu-Asn-Thr-GIu-Leu-Leu-Asn-Leu-Leu-Arg-GIu-GIn

L31 Pae Yet-Lys-Ala-Asp-Ile-His-Pro-Thr-Tyr- ? -Ala-11e-Glu-Ala-Thr- ? -Ser

Pae Met-Lys-Ala-Asp-Ile-His-Pro-Asn-Tyr-Val-Glu-Ile-Asp-Ala-Thr- ? -Ser- ? -Gly-Asn

Bdi Ala-Lys-Ala-Glu-Leu-Arg

Bve Ala-Lys-Ala-Glu-Leu-Arg

Eco Met-Lys-Lys-Asp-Ile-His-Pro-Lys-Tyr-GIu-GIu-Ile-Thr-Ala-Ser-Cys-Ser-Cys-Gly-Asn

L32 Pae Cys-Val-GIn-GIn-Asn-Lys-Lys-Ser-Arg-Ser-Ala-Arg-Asp-Met- ? - ? -Ser- ? -Asp-Ala-Leu-Glu

Pue Cys-Val-GIn-GIn-Asn-Lys-Lys-Ser-Arg-Ser-Ala-Arg-Asp-Met- ? - ? -Ser- ? -Asp-Ala-Leu-Glu

Bpi Ala-Val-GIn-GIn-Asn-Lys-Lys-Ser-Pro-Ser-Lys-Arg-Gly-Met-His-Arg-Ser-Trp-Asp-Phe-Leu-Thr

BpI Ala-Val-GIn-GIn-Asn-Lys-Lys-Ser-Pro-Ser-Lys- ? -Gly-Met-? - ? -Ser- ? -Asp- ? -Leu-Thr

Bdi Ala-Val-Pro-Lys-Arg-Lys-Val-Ser-Arg

Bve Cys-Val-Pro-Lys-Arg-Lys-Val-Ser-Pro-Ser-? -Arg-Asn-Met-Arg- ? -Ala-His-Asp- ? -Leu-Thr

Eco Ala-Yal-GIn-GIn-Asn-Lys-Pro-Thr-Arg-Ser-Lys-Arg-Gly-Met-Arg-Arg-Ser-His-Asp-Ala-Leu-Thr

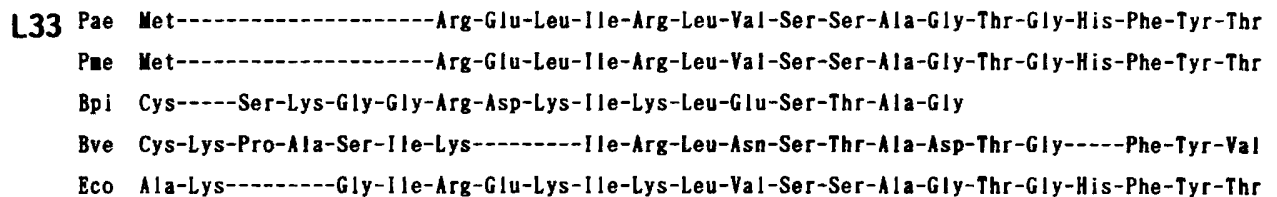

FIG. 4. Primary structures of the N termini of the L24, L27, L29, L31, L32, and L33 proteins from strains belonging to the genera Pseudomonas, Burkholderia, Brevundimonas, and Escherichia. For an explanation of the abbreviations and other details see the legend to Fig. 1.

easiest species to identify. In contrast, $P$. fluorescens is a remarkably heterogeneous species that can be subdivided on the basis of various taxonomic criteria into subspecies or biotypes or biovars. Likewise, proper taxonomic placement of some $P$. putida strains is still an open question. The members of the genus Pseudomonas which I examined had different amino acid sequences (Fig. 1). Since a level of L30 amino acid sequence homology of $100 \%$ has been detected in various Streptomyces species (16), the level of homology $(100 \%$ or $<100 \%)$ might be used to differentiate organisms at the species level. Therefore, sequence analyses of L 30 proteins may be useful for demonstrating that some $P$. fluorescens strains or $P$. putida strains are equivalent to separate species.

Ribosomes and their components have provided an excellent tool for studying the evolution of organisms, since they are essential components of all cells. Since proteins are composed of 20 different amino acids, whereas RNAs consist of only four bases, evolutionary relationships may be traced more easily by comparing ribosomal protein sequences (38). In E. coli, ribosomes contain 55 species of proteins, and all of the primary structures of these proteins are known $(8,37)$. By comparing the ribosomal proteins from $E$. coli and Bacillus stearothermophilus, Wittmann-Liebold et al. (38) found that the levels of similarity between equivalent proteins range, depending on the protein pair, from 20 to $76 \%$. High levels of sequence similarity were obtained for the S12 and L2 proteins, and the S13 and S19 proteins were less similar, implying that these proteins are functionally significant in protein synthesis. A high level of conservation of protein L2 was also demonstrated by an immunological method (28). In this study I also observed different levels of conservation for the N-terminal sequences of ribosomal protein families; the highest level of similarity was 
$S 20(126)$

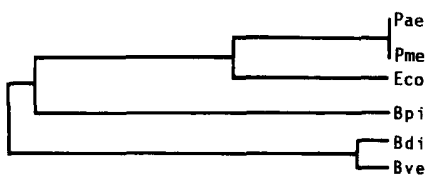

L27

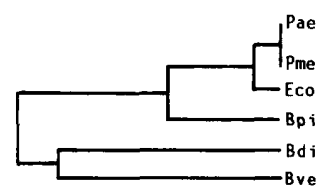

เ31

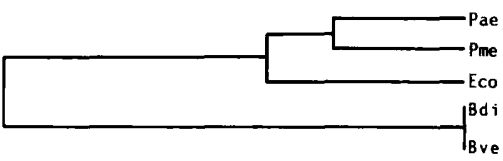

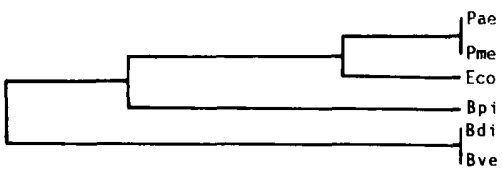

129

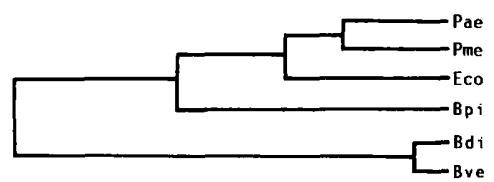

L32

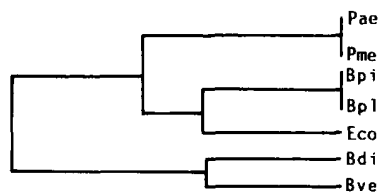

L.33

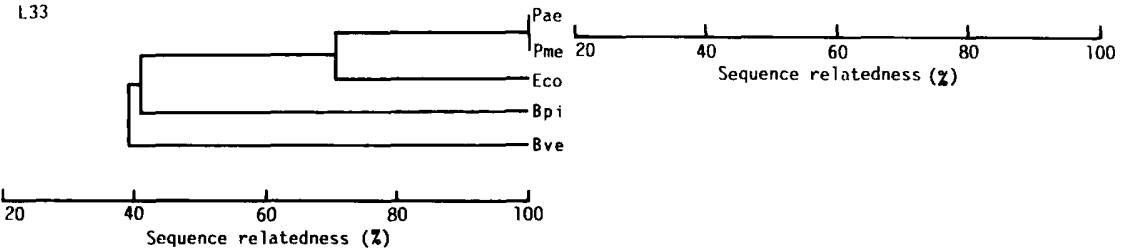

FIG. 5. Clustering based on amino acid sequence similarity values obtained for the S20, S21, L27, L29, L31, L32, and L33 proteins. The dendrogram was constructed by using the data in Fig. 3 and 4 and by comparing the first 24 amino acids (in S20), 19 amino acids (in S21), 21 amino acids (in L27), 20 amino acids (in L29 and L31), 22 amino acids (in L32), and 23 amino acids (in L33). For an explanation of the abbreviations see the legend to Fig. 1.

$74 \%$ for L27 proteins, and the lowest level of similarity was $42 \%$ for L30 proteins. As calculated by Wittmann-Liebold et al. (38), the levels of L30 protein sequence similarity between the archaebacterium Halobacterium marismortui and the bacteria $E$. coli and Bacillus stearothermophilus were as low as 25 and $23 \%$, respectively. My results, together with the results of Wittmann-Liebold et al. (38), may be taken as an indication that the function of the L30 proteins in protein synthesis is not significant and may reflect the previous observation (11) that, unlike the common bacteria having a constant relative electrophoretic mobility of 70 (see above), actinomycete genera exhibit considerable AT-L30 protein electrophoretic heterogeneity, with relative electrophoretic mobility values ranging from -6 to 100 . However, it should be stressed that despite the low level of conservation the phylogenetic branching order of the tree based on levels of L30 protein sequence similarity (Fig. 2) was essentially the same as the branching order based on other ribosomal protein data (Fig. 5). Likewise, as demonstrated by Wittmann-Liebold et al. (38), phylogenetic trees based on data for families of ribosomal proteins (S11, L12, and L2) obtained from various sources, such as eubacteria, archaebacteria, and eucaryotes, exhibit the same branching order observed in trees based on data for all ribosomal protein families examined so far. It is especially noteworthy that although the numbers of variable positions in the ribosomal protein sequences of the protein families were less than 25 , similar phylogenetic trees were constructed from my data for the various ribosomal protein families examined. Several hundred variable positions are routinely compared in $16 \mathrm{~S}$ rRNA sequencing analyses. The rather low number of variable positions used in my amino acid sequencing analyses may not be sufficient to accurately reflect phylogenetic relationships. However, the facts described above verify the efficacy of ribosomal protein sequence analysis, used in conjunction with rRNA sequence analysis, for phylogenetic investigation of microorganisms. In particular, as demonstrated in this study, L30 proteins may be useful compounds since the amounts of L30 proteins are rather large and separation of the $\mathrm{L} 30$ proteins from other ribosomal proteins by two-dimensional PAGE is sharp.

\section{ACKNOWLEDGMENTS}

This research was supported in part by a grant from the Basic Research Core System.

I thank Y. Kosako for useful discussions and R. Hayashi-Tadokoro for skillful secretarial work.

\section{REFERENCES}

1. Azegami, K., K. Nishiyama, Y. Watanabe, I. Kadota, A. Ohuchi, and C. Fukazawa. 1987. Pseudomonas plantarii sp. nov., the causal agent of rice seedling blight. Int. J. Syst. Bacteriol. 37:144-152.

2. Bowman, J. P., L. I. Sly, A. C. Hayward, Y. Spiegel, and E. Stackebrandt. 1993. Telluria mixta (Pseudomonas mixta Bowman, Sly, and Hayward 1988) gen. nov., comb. nov., and Telluria chitinolytica sp. nov., soil-dwelling organisms which actively degrade polysaccharides. Int. J. Syst. Bacteriol. 43:120124.

3. Byng, G. S., R. J. Whitaker, R. L. Gherna, and R. A. Jensen. 1980. Variable enzymological patterning in tyrosine biosynthesis as a means of determining natural relatedness among the Pseudomonadaceae. J. Bacteriol. 144:247-257.

4. De Ley, J. 1992. The Proteobacteria: ribosomal RNA cistron similarities and bacterial taxonomy, p. 2111-2140. In A. Balows, H. G. Trüper, M. Dworkin, W. Harder, and K.-H. Schleifer (ed.), The prokaryotes. A handbook on the biology of bacteria: ecophysiology, isolation, identification, applications, vol. 3. Springer-Verlag, New York.

5. De Vos, P., and J. De Ley. 1983. Intra- and intergeneric similarities of Pseudomonas and Xanthomonas ribosomal ribonucleic acid cistrons. Int. J. Syst. Bacteriol. 33:487-509.

6. De Vos, P., M. Goor, M. Gillis, and J. De Ley. 1985. Ribosomal ribonucleic acid cistron similarities of phytopathogenic Pseudomonas species. Int. J. Syst. Bacteriol. 35:169-184.

7. Kimura, M. 1984. Proteins of the Bacillus stearothermophilus ribosome. J. Biol. Chem. 259:1051-1055. 
8. Noller, H. F., M. Asire, A. Barta, S. Douthwaite, T. Goldstein, R. R. Gutell, D. Moazed, J. Normanly, J. B. Prince, S. Stern, K. Triman, S. Turner, B. Van Stolk, V. Wheaton, B. Weiser, and C. R. Woese. 1986. Studies on the structure and function of ribosomal RNA, p. 143-163. In B. Hardesty and G. Krämer (ed), Structure, function, and genetics of ribosomes. Springer-Verlag, New York.

9. Noller, H. F., D. Moazed, S. Stern, T. Powers, P. N. Allen, J. M. Robertson, B. Weiser, and K. Triman. 1990. Structure of rRNA and its functional interactions in translation, p. 73-92. In W. E. Hill, A. Dahlberg, R. A Garrett, P. B. Moore, D. Schlessinger, and J. R. Warner (ed.), The ribosome: structure, function, and evolution. American Society for Microbiology, Washington, D.C

10. Ochi, K. 1989. Heterogeneity of ribosomal proteins among Streptomyces species and its application to identification. J. Gen. Microbiol. 135:26352642.

11. Ochi, K. 1992. Electrophoretic heterogeneity of ribosomal protein AT-L30 among actinomycete genera. Int. J. Syst. Bacteriol. 42:144-150.

12. Ochi, K. 1992. Polyacrylamide gel electrophoresis analysis of ribosomal protein: a new approach for actinomycete taxonomy. Gene 115:261-265.

13. Ochi, K. 1994. Phylogenetic diversity in the genus Bacillus and comparative ribosomal protein AT-L30 analyses of the genus Thermoactinomyces and relatives. Microbiology 140:2165-2171.

14. Ochi, K. 1995. Amino acid sequence analysis of ribosomal protein AT-L30 from members of the family Pseudonocardiaceae. Int. J. Syst. Bacteriol. 45:110-115.

15. Ochi, K., K. Haraguchi, and S. Miyadoh. 1993. A taxonomic review of the genus Microbispora by analysis of ribosomal protein AT-L30. Int. J. Syst. Bacteriol. 43:58-62.

16. Ochi, K., and H. Hiranuma. 1994. A taxonomic review of the genera Kitasatosporia and Streptoverticillium by analysis of ribosomal protein AT-L30. Int. J. Syst. Bacteriol. 44:285-292.

17. Ochi, K., and S. Miyadoh. 1992. Polyacrylamide gel electrophoresis analysis of ribosomal protein AT-L30 from an actinomycete genus, Streptosporangium. Int. J. Syst. Bacteriol. 42:151-155.

18. Ochi, K., S. Miyadoh, and T. Tamura. 1991. Polyacrylamide gel electrophoresis analysis of ribosomal protein AT-L30 as a novel approach to actinomycete taxonomy: application to the genera Actinomadura and Microtetraspora. Int. J. Syst. Bacteriol. 41:234-239.

19. Palleroni, N. J. 1984. Genus I. Pseudomonas Migula 1894, p. 141-199. In N. R. Krieg and J. G. Holt (ed.), Bergey's manual of systematic bacteriology, vol. 1. The Williams \& Wilkins Co., Baltimore.

20. Palleroni, N. J. 1992. Introduction to the family Pseudomonadaceae, p. 3071-3085. In A. Balows, H. G. Trüper, M. Dworkin, W. Harder, and K.-H. Schleifer (ed.), The prokaryotes. A handbook on the biology of bacteria: ecophysiology, isolation, identification, applications, vol. 3. Springer-Verlag, New York.

21. Palleroni, N. J. 1992. Human- and animal-pathogenic pseudomonads, p. 3086-3103. In A. Balows, H. G. Trüper, M. Dworkin, W. Harder, and K.-H. Schleifer (ed.), The prokaryotes. A handbook on the biology of bacteria: ecophysiology, isolation, identification, applications, vol. 3. Springer-Verlag, New York.

22. Palleroni, N. J., and J. F. Bradbury. 1993. Stenotrophomonas, a new bacterial genus for Xanthomonas maltophilia (Hugh 1980) Swings et al. 1983. Int. J. Syst. Bacteriol. 43:606-609.

23. Palleroni, N. J., R. Kunisawa, R. Contopoulou, and M. Doudoroff. 1973. Nucleic acid homologies in the genus Pseudomonas. Int. J. Syst. Bacteriol. 23:333-339.

24. Ritter, E., and B. Wittmann-Liebold. 1975. The primary structure of protein L30 from Escherichia coli ribosomes. FEBS Lett. 60:153-155

25. Schroth, M. N., D. C. Hildebrand, and N. Panopoulos. 1992. Phytopathogenic pseudomonads and related plant-associated pseudomonads, p. 3104 3131. In A. Balows, H. G. Trüper, M. Dworkin, W. Harder, and K.-H. Schleifer (ed.), The prokaryotes. A handbook on the biology of bacteria: ecophysiology, isolation, identification, applications, vol. 3. Springer-Verlag, New York.

26. Segers, P., M. Vancanneyt, B. Pot, U. Torck, B. Hoste, D. Dewettinck, E. Falsen, K. Kersters, and P. De Vos. 1994. Classification of Pseudomonas diminuta Leifson and Hugh 1954 and Pseudomonas vesicularis Busing, Doll, and Freytag 1953 in Brevundimonas gen. nov. as Brevundimonas diminuta comb. nov. and Brevundimonas vesicularis comb. nov., respectively. Int. J Syst. Bacteriol. 44:499-510.

27. Sneath, P. H. A., M. Stevens, and M. J. Sackin. 1981. Numerical taxonomy of Pseudomonas based on published records of substrate untilization. Antonie Leeuwenhoek 47:423-448.

28. Stöffler, G., and M. Stöffler-Meilicke. 1986. Immunoelectron microscopy on Escherichia coli ribosomes, p. 28-46. In B. Hardesty and G. Krämer (ed.), Structure, function, and genetics of ribosomes. Springer-Verlag, New York.

29. Stöffler-Meilicke, M., and G. Stöffler. 1990. Topology of the ribosomal proteins from Escherichia coli within the intact subunits as determined by immunoelectron microscopy and protein-protein cross-linking, p. 123-133. In W. E. Hill, A. Dahlberg, R. A. Garrett, P. B. Moore, D. Schlessinger, and J. R. Warner (ed.), The ribosome: structure, function, and evolution. American Society for Microbiology, Washington, D.C.

30. Tamaoka, J., D.-M. Ha, and K. Komagata. 1987. Reclassification of Pseudomonas acidovorans den Dooren de Jong 1926 and Pseudomonas testosteroni Marcus and Talalay 1956 as Comamonas acidovorans comb. nov. and Comamonas testosteroni comb. nov., with an emended description of the genus Comamonas. Int. J. Syst. Bacteriol. 37:52-59.

31. Whitaker, R. J., G. S. Byng, R. L. Gherna, and R. A. Jensen. 1981. Comparative allostery of 3-deoxy-D-arabino-heptulosonate 7-phosphate synthetase as an indicator of taxonomic relatedness in pseudomonad genera. $\mathbf{J}$. Bacteriol. 145:752-759.

32. Whitaker, R. J., G. S. Byng, R. L. Gherna, and R. A. Jensen. 1981. Diverse enzymological patterns of phenylalanine biosynthesis in pseudomonad bacteria are conserved in parallel with DNA-DNA homology groupings. J. Bacteriol. 147:526-534.

33. Willems, A., J. Busse, M. Goor, B. Pot, E. Falsen, E. Jantzen, B. Hoste, M. Gillis, K. Kersters, G. Auling, and J. De Ley. 1989. Hydrogenophaga, a new genus of hydrogen-oxidizing bacteria that includes Hydrogenophaga flava comb. nov. (formerly Pseudomonas flava), Hydrogenophaga palleronii (formerly Pseudomonas palleronii), Hydrogenophaga pseudoflava (formerly Pseudomonas pseudoflava and "Pseudomonas carboxydoflava"), and Hydrogenophaga taeniospiralis (formerly Pseudomonas taeniospiralis). Int. J. Syst. Bacteriol. 39:319-333.

34. Willems, A., E. Falsen, B. Pot, E. Jantzen, B. Hoste, P. Vandamme, M. Gillis, K. Kersters, and J. De Ley. 1990. Acidovorax, a new genus for Pseudomonas facilis, Pseudomonas delafieldii, EF group 13, EF group 16, and several clinical isolates, with the species Acidovorax facilis comb. nov., Acidovorax delafieldii comb. nov., and Acidovorax temperans sp. nov. Int. J. Syst. Bacteriol. 40:384-398.

35. Wittman, H. G. 1976. Structure, function and evolution of ribosomes. Eur. J. Biochem. 61:1-13.

36. Wittmann, H. G. 1986. Structure of ribosomes, p. 1-27. In B. Hardesty and G. Krämer (ed.), Structure, function, and genetics of ribosomes. SpringerVerlag, New York.

37. Wittmann-Liebold, B. 1986 . Ribosomal proteins: their structure and evolution, p. 326-361. In B. Hardesty and G. Krämer (ed.), Structure, function, and genetics of ribosomes. Springer-Verlag, New York.

38. Wittmann-Liebold, B., A. K. E. Köpke, E. Arndt, W. Krömer, T. Hatakeyama, and H. G. Wittmann. 1990. Sequence comparison and evolution of ribosomal proteins and their genes, p. 598-616. In W. E. Hill, A. Dahlberg, R. A. Garrett, P. B. Moore, D. Schlessinger, and J. R. Warner (ed.), The ribosome: structure, function, and evolution. American Society for Microbiology, Washington, D.C.

39. Woese, C. R., P. Blanz, and C. M. Hahn. 1984. What isn't a pseudomonad: the importance of nomenclature in bacterial classification. Syst. Appl. Microbiol. 5:179-195.

40. Yabuuchi, E, Y. Kosako, H. Oyaizu, I. Yano, H. Hotta, Y. Hashimoto, T. Ezaki, and M. Arakawa. 1992. Proposal of Burkholderia gen. nov. and transfer of seven species of the genus Pseudomonas homology group II to the new genus, with the type species Burkholderia cepacia (Palleroni and Holmes 1981) comb. nov. Microbiol. Immunol. 36:1251-1275.

41. Yabuuchi, E., I. Yano, H. Oyaizu, Y. Hashimoto, T. Ezaki, and H. Yamamoto. 1990. Proposals of Sphingomonas paucimobilis gen. nov. and comb. nov., Sphingomonas parapaucimobilis sp. nov., Sphingomonas yanoikuyae sp. nov., Sphingomonas adhaesiva sp. nov., Sphingomonas capsulata comb. nov., and two genospecies of the genus Sphingomonas. Microbiol. Immunol. 34:99-119. 